\title{
FROM REPRODUCTIVE HEALTH TO UNPREPARED HEALTH SYSTEM STRUCTURE: REMEMBERING WHY WE START THE DIGITAL HEALTH
}

\author{
Dari Kesehatan Reproduksi hingga Belum Siapnya Struktur Sistem Kesehatan: \\ Mengingat Mengapa Kita Memulai Kesehatan Berbasis Digital
}

\author{
Nuzulul Kusuma Putri, S.KM., M.Kes \\ Editor-In-Chief of Indonesian Journal of Health Administration \\ Department of Health Administration and Policy, Airlangga University, Indonesia \\ Email: nuzululkusuma@fkm.unair.ac.id
}

The COVID-19 pandemic brought blessings in disguise to how we should run the new era of digital health. As the developing country with unsolved health problems, Indonesia needs some "forces" to reach the new era of health digitalization. This era is the time to enter the new order of healthcare services. The Volume 8 Number 1 was prepared before the pandemic started, but the articles were totally related to the ongoing disruption. We published our current edition by underlining the prospective of digital health on their respect of old-fashioned health problems in Indonesia. Three main topics were covered in this edition; how we start the digital health, what should be prepared, and what health problems should be addressed.

\section{Never Ending Story of Reproductive Health Problems}

Maternal mortality remains a problem for Indonesia. Even though it has been decreasing since 2000, the Maternal Mortality Rate in Indonesia is still high (177 per 100,000 live births in 2017) (United Nations Children's Fund, 2019). Acknowledging that the Maternal Mortality Rate is preventable, Indonesia was committed to sign the 1994 International Conference on Population and Development (ICPD). This commitment is the cornerstone for countries throughout the world in mainstreaming the reproductive health in every population and development programs (United Nations Population Fund, 1994). Nowadays, the ICPD is still relevant, and it has then been transformed into various health strategies including the Sustainable Development Goals (SDGs).

Operationalizing their commitment on reproductive health, Indonesia has implemented various health programs. Our authors underlined the two most recent programs designed by the Government in handling the reproductive health problems in Indonesia, i.e. the Family Planning Village Program and Breastfeeding Support Group Program. Even though both of these programs were built based on the concept of community empowerment, our authors in these two articles used a different research method in investigating the program's effectiveness.

Using a mixed-method approach, Huda, Baroya, Sandra, and Hariastuti (2020) concluded that the implementation of the Family Planning Village is promising to raise the acceptance of long-term contraceptive method among couples in childbearing age. Their study suggested that improving communication skill of health cadres would definitely boost the successfulness possibility of these 
programs. An article written by Hasanah, Putri, and Pramono (2020) also pointed out similar results of the Breastfeeding Support Group Program. By comparing two different designs of program in the community, they showed the important factors that should be accommodated to sustain community empowerment programs on reproductive health. We also presented an article that discussed about reproductive healthcare for marginalized people. Noffritasari, Shaluhiyah and Adi (2020) reported that stigmatization is still bold issue yet unaddressed barrier in providing accessible reproductive healthcare for Lesbian Gay Bisexual and Transgender community. Echoing what Huda et al. (2020) have suggested, Noffritasari, Shaluhiyah and Adi (2020) also suggested that communication skill of health providers is important for the program.

\section{Unprepared Structure of Health System}

Health system is composed by its correlated components. What happened in the outcome is determined by the structure and the process that engine the system itself. This edition also underlined what should be repaired in the structure and process of the health system.

Laksono, Ridlo, and Ernawaty (2020) reopened our memory to the unequal distribution of physicians in Indonesia. The issue of health provider distribution has still been happening even after Indonesia has implemented various policies for its human workforce and decentralization. Their article suggested the emerging of redistribution policy in Indonesia. Another article in this edition also strengthened the code blue condition in Indonesia health workers condition. Different from Laksono, Ridlo, and Ernawaty (2020), the two other papers focused on how the health workforce plays a role more in health policy implementation rather than as the policy object.
Rahmawati and Prastika (2020) conducted their study in one of the government-owned hospitals that regulates generic drug prescription for their patients. They reported the lack of physicians' knowledge of the generic drugs prescription. Their paper reported that there was a strong correlation between the specialization of physicians and their responsibility for pescribing generic drugs. Even though the physicians had a great sense of responsibility in prescribing generic drugs, insufficient knowledge on this topic would lead them to ineffective policy of generic drug prescription.

Physicians are responsible to not only provide standardized medical treatments but also make their hospital survive in the high-cost industry. A paper written by Siswanto and Chalidyanto (2020) reported a surprising result which mentioned that compliance of physicians with the clinical pathway did not bring any significant change on the patients' length of stay. This paper raised numerous potential factors that the hospital management should consider to shortening the length of stay more rather than pushing their doctors'clinical pathway compliance.

\section{The Emerging Digital Health}

In 2020, World Health Organization published their first draft on Global Strategy on Digital Health 2020-2024. It was mentioned that this draft aimed to promote healthy lives and well-being for everyone and everywhere at all ages (World Health Organization, 2020). This strategy explains the demand on the integration of financial, organizational, human and technological resources in the digital health implementation. The COVID19 pandemic was believed as the turning point for every single country to build their digital health. The rising of digital health platform happened not only in developed countries but also in low and middle countries. It revolutionizes how people access 
healthcare services to promote their health and well-being.

In this edition, we highlighted the rising of digital health issues by choosing two articles. The first article presentd how the local government in Indonesia has tried to promote the e-health at primary healthcare centers. Adian and Budiarto (2020) reviewed that e-health successfully provides an accessible route for lay people to reach primary healthcare centers. It minimized the opportunity loss during accessing healthcare. It is easy for some people but still hard for people with low literacy. Patel (2020) presented the possible problems resulted from unprepared digital health implementation. She underlined the importance of healthcare organization to secure their data system. Social engineering attacks in healthcare organizations was explained by considering the vulnerabilities of digital health data system. Her article also presented the prevention measures which health mangers who develop the digital health data system should understand.

All in all, this edition brought an insightful study that translated how should health managers deal with the development of digital health. Digital health is the future of healthcare services, but health managers should also aware of the journey of health system up to this period. The issues from reproductive health to unprepared health system structure must be addressed in the digital health. Remembering why we start the digital health will help us innovate and survive during the digital health disruption.

\section{REFERENCES}

Adian, Y. A. P. and Budiarto, W. (2020) 'Literature Review: the Implementation of E-Health At Primary Healthcare Centers in Surabaya City', Jurnal Administrasi Kesehatan Indonesia, 8(1), pp. 40-
55.

Fund, U. N. P. (1994) Programme of Action International Conference on Population and Development. United Nations Population Fund. doi: 10.1057/9780230589780_31.

Hasanah, D. R., Putri, N. K. and Pramono, A. Y. (2020) 'Effectiveness of Forming Breastfeeding Support Group Program to Improve Exclusive Breastfeeding', Jurnal Administrasi Kesehatan Indonesia, 8(1), pp. 5-19.

Huda, N. et al. (2020) 'Family Planning Village Program in Response to The Use of Long-term Contraceptive Method', Jurnal Administrasi Kesehatan Indonesia, 8(1), pp. 7990.

Laksono, A. D., Ridlo, I. A. and Ernawaty, E. (2019) 'Distribution Analysis of Doctors in Indonesia', Jurnal Administrasi Kesehatan Indonesia, 8(1), pp. 29-39. doi: 10.31227/osf.io/df6ns.

Noffritasari, B., Shaluhiyah, Z. and Adi, M. S. (2020) 'Human Immunodeficiency Virus (HIV) Prevention Program Among Men Who Have Sex With Men (MSM) in Semarang City', Jurnal Administrasi Kesehatan Indonesia, 8(1), pp. 91-106.

Patel, N. (2020) 'Social Engineering As an Evolutionary Threat to Information Security in Healthcare Organizations', Jurnal Administrasi Kesehatan Indonesia, 8(1), pp. 5563. doi: 10.20473/jaki.v7i2.2019.132138.

Rahmawati, I. and Prastika, V. I. D. (2020) 'Physician Knowledge and Responsibility of Prescription Policy', Jurnal Administrasi Kesehatan Indonesia, 8(1), pp. 20-28.

Siswanto, M. and Chalidyanto, D. (2020) 'The Effect of Clinical Pathway Compliance in Reducing Length of Stay', Jurnal Administrasi Kesehatan Indonesia, 8(1), pp. 65-78.

United Nations Children's Fund (2019) Trends in Maternal Mortality Estimates by WHO, UNICEF, UNFPA, World Bank Group and the UN Population Division. New York. Available at: https://data.unicef.org/resources/tren 
[DAKI

JURNAL ADMINISTRASI

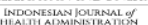

ds-maternal-mortality-2000-2017/.

World Health Organization (2020) Draft global strategy on digital health 2020

- 2024. Available at:

Jurnal Administrasi Kesehatan Indonesia Volume 8 No 1 June 2020

Published by Universitas Airlangga Doi: 10.20473/jaki.v8i1.2020.1-4

https://www.who.int/docs/defaultsource/documents/gs4dhdaa2a9f35 2b0445bafbc79ca799dce4d.pdf?sfvr $\mathrm{sn}=f 112$ ede5_42. 